\title{
Catecholamine-binding Brain Protein in Mice Exposed to Perinatal Malnutrition and Neonatal Infection
}

\author{
CHI-JEN LEE \\ National Institute of Child Health and Human Development, National Institutes of Health, Bethesda, Maryland,
} $U S A$

\section{Extract}

The formation and specific activity of a catecholamine-binding brain protein were studied in mice exposed to perinatal malnutrition and neonatal infection.

In the malnourished group, the total norepinephrine (NE)-binding protein was less than in the control group (malnourished 7.1 10.0 mg; control $13.0-14.0 \mathrm{mg}$ ), but the dopamine (DM)-binding protein was not significantly affected. In the infected group, the quantity of NE-binding protein was also decreased (infected 6.4-8.0 mg), but the DM-binding protein was higher than in the control group.

The specific and total binding activity of $\left[{ }^{3} \mathrm{H}\right] \mathrm{NE}$ to brain protein was greatly reduced in the infected group (infected $22.6 \mathrm{pmol} / \mathrm{mg}$ protein; control $88.4 \mathrm{pmol} / \mathrm{mg}$ protein), and decreased also in the guanidine- $\mathrm{HCl}$ eluate of the malnourished group $(56.5 \mathrm{pmol} / \mathrm{mg}$ protein $)$. The binding activity of $\left[{ }^{14} \mathrm{C}\right] \mathrm{DM}$ was decreased markedly in the infected group (infected $131 \mathrm{pmol} / \mathrm{mg}$ protein; control 330 $\mathrm{pmol} / \mathrm{mg}$ protein), but its specific binding activity was not as severely affected in the malnourished as in the infected group.

The molecular weights of the catecholamine-binding protein were 75,000 in the control, 70,000 in the malnourished and 65,000 in the infected groups.

There were no marked differences between the malnourished and control groups with regard to the amino acid composition of the NE-binding protein. The DM-binding protein in these animals had decreased amino acid content. The infected group exhibited re markable changes in NE- and DM-binding brain protein.

\section{Speculation}

Catecholamine-binding brain protein may be related to the specific protein in the storage granules in the formation of NEATP-protein complex, or it may be a part of a receptor molecule in postsynaptic cells. Perinatal malnutrition and neonatal infection may result in a derangement of catecholamine metabolism. The impaired formation of the synaptic connection may account for some of the functional changes of brain development.

The brain development and metabolic activities of individuals can be profoundly and lastingly altered by early malnutrition during gestation and lactation and by neonatal infection $(1,18,32$, 38). The effects of such perinatal physiologic stresses persist throughout the whole lifespan of the young, even if attempts are made to correct them by placing the animals under optimum conditions or by supplying an adequate diet after weaning and during adult life.

We have described eartier that early malnutrition and neonatal infection of mice exert lasting influences on the metabolisms of brain protein, cyclic AMP, and catecholamine. Early malnutrition and neonatal infection were found to impair the biosynthesis and structure of brain protein (17), 10 alter cyclic AMP metabolism, and to decrease the binding ability of cyclic AMP to synaptosomes (21). Such stresses also depressed the brain contents in NE and DM (22).
The specific binding of norepinephrine to microsomal particles of cardiac muscle exhibits similarities to the binding of catecholamine to the $\beta$-adrenergic receptor $(23,25)$. Such binding of catecholamine and receptor sites may stimulate adenyl cyclase activity in the formation of adenosine $3^{\prime}, 5^{\prime}$-monophosphate (cyclic AMP). The binding of catecholamine to its receptor leading to the activation of adenyl cyclase and the accumulation of cyclic AMP has also been observed in the erythrocyte membrane system (3, $33)$, and in the brain $(5,16)$. On the other hand, the $\beta$-adrenergic receptor exhibited strict stereospecificity for $(-)$-catecholamines (35). The binding of $\left[{ }^{3} \mathrm{H}\right] \mathrm{NE}$ to intact fat cells of the rat and heart microsomes seemed not to measure catecholamine receptor interactions, but rather a membrane catecholamine binding protein which might be related to the enzyme catechol- $O$-methyltransferase $(7,9)$. The binding of $\left[{ }^{3} \mathrm{H}\right] \mathrm{NE}$ to the catecholamine-binding protein in mouse brain might not be related to the affinity between $\mathrm{NE}$ and the enzyme catechol- $O$-methyltransferase. The specific binding activity of brain protein to $\left[{ }^{3} \mathrm{H}\right] \mathrm{NE}$ could be significantly inhibited by the enzymatic digestion with neuraminidase and treatment with nucleotides. This brain protein contained two distinct fractions which had different affinity for binding NE and different response to the treatments with neuraminidase, trypsin, and propranolol (19)

The present report will describe $(l)$ the solubilization of catecholamine-binding brain protein and its isolation and purification by affinity chromatography, and (2) the effects of perinatal malnutrition and neonatal infection on the formation, specific activity, and structure of catecholamine-binding brain proteins. Either NE or DM was linked covalently to the matrix of agarose beads. Such catecholamine-agarose conjugate was used for affinity chromatography. Changes in brain protein structure were studied by determination of molecular weights and amino acid compositions.

\section{MATERIALS AND METHODS}

\section{ENTEROVIRUS AND EXPERIMENTAL ANIMALS}

The origin of the mouse enterovirus preparation used in the present study has been described in an earlier paper (20).

Specific pathogen-free mice of the COBS strain (40) were used in all experiments.

The malnourished group consisted of the progeny of mothers fed a diet containing $20 \%$ wheat gluten as the sole protein source. The dams were placed on the gluten diet from day 14 of pregnancy to day 21 after delivery (17). After weaning all animals were transferred to $D \& G$ pellets (41). Control animals were kept on a $D \& G$ diet throughout the duration of the experiment.

PREPARATION OF NOREPINEPHRINE OR DOPAMINE-AGAROSE CONJUGATE FOR AFFINITY CHROMATOGRAPHY

Agarose beads were activated with cyanogen bromide at alkaline $\mathrm{pH}$ and coupled with a primary aliphatic hydrocarbon side chain. Catecholamine was bound covalently to the hydrocarbon 
side chain of agarose matrix $(6,8,24)$. Sepharose 4B (42) $200 \mathrm{~g}$, was suspended in $400 \mathrm{ml}$ distilled water. Cyanogen bromide $(40 \mathrm{~g})$ (43) was added to the stirred suspension in an ice-bath, and the $\mathrm{pH}$ was adjusted to 11 . The agarose was washed with $0.5 \mathrm{M}$ sodium bicarbonate solution. The wet agarose was treated with $26.2 \mathrm{~g}$ 3,3'-diaminodipropylamine (43) in $500 \mathrm{ml}, 0.5 \mathrm{M}$ sodium bicarbonate solution and the mixture stirred gently at $4^{\circ}$ overnight. The substituted agarose was then washed with distilled water.

The aminated agarose was succinylated at $4^{\circ}$ by the addition of $50 \mathrm{~g}$ succinic anhydride and adjusted to $\mathrm{pH} 6$. The reaction mixture was kept at $4^{\circ}$ overnight. The succinylated agarose was washed with $0.1 \mathrm{M}$ potassium chloride, then with distilled water and suspended in $400 \mathrm{ml}$ distilled water at room temperature. The suspension received $5.2 \mathrm{~g}$ diaminodipropylamine and the $\mathrm{pH}$ was adjusted to 4.8 . Then $32 \mathrm{~g}$ coupling reagent, 1-cyclohexyl-3-(2morpholinoethyl)-carbodiimide metho- $p$-toluene sulfonate (44) or $N, N$-dicyclohexyl carbodiimide (44) was added, and the $\mathrm{pH}$ was kept at 4.8. The suspension was stirred gently overnight at room temperature and then washed with $1 \mathrm{mM}$ hydrochloric acid and distilled water. The free amino groups were succinylated again under the conditions described previously.

The mixture was suspended in distilled water at room temperature, adjusted to $\mathrm{pH} \mathrm{4.8}$. and divided equally into two parts. One part received $2 \mathrm{ml} 0.5 \mathrm{M}$ norepinephrine- $\mathrm{HCl}$ in $0.1 \mathrm{~N}$ hydrochloric acid, containing $200 \mu \mathrm{Ci}$ of DL- $\left[7-{ }^{3} \mathrm{H}\right]$ norepinephrine (specific activity $3.0 \mathrm{Ci} / \mathrm{mmol}(44))$. The other part received $2 \mathrm{ml} 0.5 \mathrm{M}$ dopamine, containing $20 \mu \mathrm{Ci}\left[2-{ }^{14} \mathrm{C}\right]$ dopamine (specific activity, 25 $\mathrm{mCi} / \mathrm{mmol}(44))$. The NE or DM was coupled by the subsequent addition of $5 \mathrm{~g}$ coupling reagent, adjusted to $\mathrm{pH} 4.8$ and kept overnight at room temperature with stirring. The catecholamineagarose was washed with $1 \mathrm{mM}$ hydrochloric acid, water, and suspended in an equal volume of water.

\section{EXTRACTION OF BRAIN PROTEIN WITH DETERGENT AND AFFIN-} ITY CHROMATOGRAPHY

Mouse brain proteins at particulate binding sites were solubilized and extracted with the detergent. Triton X-100 (45), sodium deoxycholate, or Lubrol PX (46). The same quantity of brains from both experimental and control animals were used (the size of brain was smaller in experimental animals, thus a larger number was included in these groups). Brains were homogenized in $0.25 \%$ detergent solution and centrifuged at $105,000 \times g$ for $1 \mathrm{hr}$. The pellets were re-extracted with detergent solution. Portions of brain extract were placed on NE- or DM-agarose columns, $0.8 \times 4 \mathrm{~cm}$. After the samples were run through, the column was washed with pH 7.3 buffer ( $5 \mathrm{mM}$ Tris-phosphate solution). The bound brain protein was eluted with $4 \mathrm{M}$ sodium chloride, followed by washing with pH 7.3 buffer. The column was then eluted with $4 \mathrm{M}$ guanidine- $\mathrm{HCl}$. The eluates were dialyzed separately against distilled water and pH 7.3 buffer to remove sodium chloride or guanidine- $\mathrm{HCl}$. The column run-through and buffer washing were analyzed for protein contents by colorimetry, and the binding activity for $\left[{ }^{3} \mathrm{H}\right] \mathrm{NE}$ or $\left[{ }^{14} \mathrm{C}\right] \mathrm{DM}$.

\section{SPECIFIC BINDING ACTIVITY OF $\left[{ }^{3} H\right]$ NOREPINEPHRINE AND} $\left[{ }^{14} \mathrm{C}\right]$ DOPAMINE TO BRAIN PROTEIN

The binding activity of radioactive ligands to brain protein was measured by equilibrium dialysis. Aliquots of $0.6 \mathrm{mg}$ brain protein in $1.5 \mathrm{ml}$ Tris-buffer, $\mathrm{pH} 7.3(0.01 \mathrm{M}$ Tris-hydrochloride, $2 \mathrm{mM}$ magnesium chloride, $0.6 \mathrm{mM} \beta$-mercaptoethanol) were placed in the dialysis membrane tube $(1 \mathrm{~cm}$ wide (47)) and dialyzed against $10 \mathrm{ml} 0.2 \mu \mathrm{Ci}$ DL- $\left[7-{ }^{3} \mathrm{H}\right]$ norepinephrine or $0.1 \mu \mathrm{Ci}\left[2-{ }^{14} \mathrm{C}\right] \mathrm{dopa}-$ mine in the same buffer solution for $24 \mathrm{hr}$ at $4^{\circ}$ on a rotary shaker. Equilibrium was reached under these conditions. The radioactive ligand bound to brain protein was calculated by subtracting the radioactivity of dialysate from that inside the tube.
PURIFICATION OF BRAIN PROTEIN BY SEPHADEX G-25 AND G-100 CHROMATOGRAPHY AND SPECIFIC BINDING FOR ${ }^{3} \mathrm{H} \mid N E$ AND $\left[{ }^{14} \mathrm{C}\right] \mathrm{DM}$

Brain proteins isolated by alfinity chromatography (eluates of sodium chloride and guanidine- $\mathrm{HCl}$ ) were combined together for further purification. These proteins were dissolved in $\mathrm{pH} 7.5$ Tris-buffer, received $10 \mu \mathrm{Ci}\left[{ }^{3} \mathrm{H}\right] \mathrm{NE}$ or $1 \mu \mathrm{Ci}\left[{ }^{1+} \mathrm{C}\right] \mathrm{DM}$, and were incubated at $37^{\circ}$ for $1 \mathrm{hr}$. The mixtures were dialyzed in $\mathrm{pH} 7.5$ Tris-buffer at $4^{\circ}$ to remove free labeled compounds. The dialysates were lyophilized and dissolved in $0.1 \mathrm{M}$ ammonium bicarbonate. A Sephadex G-25 (42) column, $2 \times 40 \mathrm{~cm}$, was equilibrated with 0.1 $\mathrm{M}$ ammonium bicarbonate. The protein samples were applied to the top of the column and the chromatography was carried out at $25^{\circ}$. For each $2.5 \mathrm{ml}$ fraction, the optical density at $280 \mathrm{~nm}$ was measured by spectrophotometry, and the radioactivity measured by scintillation counter. The peak fractions were combined together. condensed, and passed through a Sephadex G-100 column, $1.6 \times 54 \mathrm{~cm}$, equilibrated with $0.1 \mathrm{M}$ ammonium bicarbonate. The optical density at $280 \mathrm{~nm}$ and radioactivity were determined by the method described previously.

\section{SODIUM DODECYL SULFATE-POLYACRYLAMIDE GEL ELECTRO- PHORESIS}

Brain protein samples were treated with sodium dodecyl sulfate (48) and fractionated in $10 \%$ polyacrylamide gel disc electrophoresis $(49)(11,37)$.

\section{MOLECULAR WEIGHT DETERMINATION OF BRAIN PROTEIN}

Estimation of molecular weight of brain protein was performed by the Sephadex gel filtration method (2). Sephadex G-100 was packed into a chromatographic column $(2 \times 58 \mathrm{~cm})$ until a gel height of $52 \mathrm{~cm}$ was reached. The column was equilibrated with $0.05 \mathrm{M}$ Tris-hydrochloride buffer, $\mathrm{pH} 7.5$, containing $0.1 \mathrm{M}$ potassium chloride. Various protein standards including glucagon, lactalbumin, ovalbumin, bovine serum albumin, cytochrome $c$ (50), ribonuclease, hexokinase (51), and mouse brain protein fractions were dissolved separately in $\mathrm{pH} 7.5$ Tris-buffer $(10 \mathrm{mg}$ protein in $2 \mathrm{ml}$ ) and the solutions were applied to the top of column (two protein standards at a time). The flow rate of column was maintained at approximately $30 \mathrm{ml} / \mathrm{hr}$ at room temperature. The optical density at $280 \mathrm{~nm}$ in each $6-\mathrm{ml}$ fraction was measured by spectrophotometry. The effluent volume corresponding to the maximum concentration of the respective protein was determined. The molecular weight of brain protein was estimated from the plots of elution volume against the log molecular weight for standard protein.

\section{AMINO ACID ANALYSES}

Amino acid analyses were done with the Beckman model $120 \mathrm{C}$ amino acid analyzer (30). Protein samples were hydrolyzed in vacuo with $6 \mathrm{~N}$ hydrochloric acid for $20 \mathrm{hr}$ at $110^{\circ}$ (34). The hydrochloric acid was removed at $25^{\circ}$ by a Büchi Rotavapor-R (52). The residues were dissolved in $0.2 \mathrm{~N}$ sodium citrate buffer, $\mathrm{pH} 2.2$, and filtered through a $0.45-\mu \mathrm{m}$ Millipore filter.

\section{RESULTS}

SOLUBILIZATION OF BRAIN PROTEIN BINDING TO CATECHOLAMINE

Brain protein localized in particulate sites was solubilized with the detergents, Triton X-100, sodium deoxycholate, or Lubrol PX. After treatment with detergents, about $13.4-27.0 \%$ more protein was extracted by the buffer solution, and the specific binding activity to catecholamine increased in parallel. Generally, solubilization with Lubrol PX was more effective than with Triton X-100 or sodium deoxycholate. At a concentration of $0.25 \%$ detergent, 
brain extract prepared by Lubrol PX bound 1.77 pmol of $\left[{ }^{3} \mathrm{H}\right] \mathrm{NE} / \mathrm{mg}$ protein, whereas sodium deoxycholate bound 0.486 pmol, and Triton X-100 bound 1.18 pmol. Lubrol PX bound 24.7 pmol $\left[{ }^{14} \mathrm{C}\right] \mathrm{DM}$, sodium deoxycholate bound $16.7 \mathrm{pmol}$, and Triton X-100 bound $10.7 \mathrm{pmol} / \mathrm{mg}$ protein.

\section{ISOLATION AND PURIFICATION OF CATECHOLAMINE-BINDING} PROTEIN BY AFFINITY CHROMATOGRAPHY

The solubilized brain proteins were purified by affinity chromatography in which catecholamine-binding proteins were bound tightly to the column. The bound proteins can be eluted with the solvent which dissociates them from the column. In the present experiment, the reversible and specific interaction of catecholamine-binding protein with NE or DM was achieved by affinity chromatography. When the brain protein solution was added to the column of NE-agarose conjugate, $40-64 \%$ of the protein passed through; 64.6-75.0\% protein passed through the DM-agarose column (Tables 1 and 2). Norepinephrine binding activity has been reported to be eluted from the column with $0.1 \mathrm{M}$ epinephrine at pH $3.8(24)$. In the present experiments, the brain protein bound to the NE-agarose column could not be eluted with $0.1 \mathrm{M}$ or more concentrated epinephrine. The protein was bound tightly to the column and could be eluted with $4 \mathrm{M}$ sodium chloride and $4 \mathrm{M}$ guanidine- $\mathrm{HCl}$. NE-binding protein was eluted from the column to the extent of $16.9-25.4 \%$ of total protein by $4 \mathrm{M}$ sodium chloride and $6.5-23.0 \%$ by $4 \mathrm{M}$ guanidine- $\mathrm{HCl}$. A smaller proportion of DM-binding protein was bound to the column: $8.9-15.4 \%$ of it was eluted by $4 \mathrm{M}$ sodium chloride and $6.5-15.4 \%$ by $4 \mathrm{M}$ guanidine$\mathrm{HCl}$.

CATECHOLAMINE-BINDING BRAIN PROTEIN IN MICE EXPOSED TO PERINATAL MALNUTRITION AND NEONATAL INFECTION

Tables 1 and 2 show the NE- or DM-binding brain protein isolated by affinity chromatography in malnourished and infected mice. As observed in the control group, more protein was obtained in the detergent-extracted fraction of the experimental groups.

In the malnourished animals, the protein content of the $\mathrm{pH} 7.3$ buffer extract was much lower than in the control group. The total NE-binding protein isolated by affinity chromatography in the malnourished group was $7.1 \mathrm{mg}$ against $13.0 \mathrm{mg}$ in the control group. The protein content of eluates for the detergent-extracted fraction was $10.0 \mathrm{mg}$ in malnourished mice and $14.0 \mathrm{mg}$ in the control group. In the malnourished animals, the total DM-binding protein content was essentially the same in the detergent-extracted as in the $\mathrm{pH} 7.3$ buffer fractions. It was not significantly different from that of the control group.

The protein content of $\mathrm{pH} 7.3$ buffer extract as well as the detergent extract fractions was greatly reduced in the infected animals. The total NE-binding protein obtained from sodium chloride and guanidine- $\mathrm{HCl}$ eluates was decreased: $6.4-8.0 \mathrm{mg}$ in the infected group as compared with 13.0-14.0 in the control group. Detergent solubilization did not increase the yield of DM-binding protein as compared with $\mathrm{pH} 7.3$ buffer fraction. However, the total DM-binding protein obtained by affinity chromatography was higher than in the controls; $11.9-12 \mathrm{mg}$ in the infected group as against $5.38 .5 \mathrm{mg}$ in the control group.

\section{BINDING ACTIVITY OF $\left[{ }^{3} \mathrm{H}\right] \mathrm{NE}$ AND $\left[{ }^{19} \mathrm{C}\right] \mathrm{DM}$ TO BRAIN PROTEIN}

Tables 3 and 4 show the binding activity of $\left[{ }^{3} \mathrm{H}\right] \mathrm{NE}$ and $\left[{ }^{14} \mathrm{C}\right] \mathrm{DM}$ to the brain protein of malnourished and infected mice. In general, the binding activity of $\left[{ }^{3} \mathrm{H}\right] \mathrm{NE}$ and $\left[{ }^{14} \mathrm{C}\right] \mathrm{DM}$ to brain protein was higher in the particulate fraction solubilized with detergent than in the soluble fraction. More binding activity was recovered in the eluates of sodium chloride and guanidine- $\mathrm{HCl}$ than in the original brain extract. This may be because of the removal of an inhibitor of binding. Recombination of the separated fractions to the original brain extract would decrease their specific binding activities.

In malnourished mice, the specific binding activity of $\left[{ }^{3} \mathrm{H}\right] \mathrm{NE}$ to brain protein was as high or higher than in the control group with regard to both the soluble and the particulate fractions of brain extracted with sodium chloride; the protein fraction obtained from guanidine- $\mathrm{HCl}$ showed low binding activity. The total $\left[{ }^{3} \mathrm{H}\right] \mathrm{NE}$ binding activities were decreased in malnourished animals, perhaps because of the low quantity of protein. In infected animals, the specific or total binding activity of $\left[{ }^{3} \mathrm{H}\right] \mathrm{NE}$ was greatly reduced in the brain extract and in the eluate from affinity chromatography. The total binding activity in soluble fraction was 216 pmol

Table 1. Norepinephrine-binding brain protein, solubilized with detergent and isolated by affinity chromatography ${ }^{1}$

\begin{tabular}{|c|c|c|c|c|c|c|c|c|}
\hline \multirow[b]{2}{*}{$\begin{array}{l}\text { Brain protein } \\
\text { solubilized with } \\
\text { detergent }\end{array}$} & \multicolumn{4}{|c|}{ Control } & \multicolumn{2}{|c|}{ Perinatal malnutrition } & \multicolumn{2}{|c|}{ Neonatal infection } \\
\hline & $\begin{array}{l}\mathrm{pH} 7.3 \\
\text { buffer }\end{array}$ & $\begin{array}{l}\text { Triton } \\
X-100\end{array}$ & $\begin{array}{l}\text { Sodium } \\
\text { deoxy- } \\
\text { cholate }\end{array}$ & Lubrol PX & $\begin{array}{l}\text { pH } 7.3 \\
\text { buffer }\end{array}$ & Lubrol PX & $\begin{array}{l}\mathrm{pH} 7.3 \\
\text { buffer }\end{array}$ & Lubrol PX \\
\hline \multicolumn{9}{|l|}{ Protein content, mg } \\
\hline Brain extract $(5 \mathrm{ml})$ & 30.7 & 34.8 & 36.5 & 39.0 & 21.8 & 32.5 & 22.5 & 25.5 \\
\hline $\begin{array}{l}\text { Pass through column and } \\
\text { washing }\end{array}$ & 12.3 & 17.9 & 28.0 & 23.4 & 11.2 & 14.7 & 10.0 & 10.0 \\
\hline \multicolumn{9}{|l|}{ Eluate } \\
\hline $4 \mathrm{M} \mathrm{NaCl}$ protein, $\mathrm{mg}$ & 7.80 & 8.64 & 6.17 & 8.45 & 3.25 & 5.70 & 4.50 & 5.00 \\
\hline $4 \mathrm{M} \mathrm{NaCl}$ protein, $\%$ & $(25.4)$ & $(24.8)$ & $(16.9)$ & $(21.6)$ & $(14.9)$ & $(17.5)$ & $(20.0)$ & (19.6) \\
\hline $\begin{array}{l}4 \mathrm{M} \text { guanidine- } \mathrm{HCl} \text { protein, } \\
\mathrm{mg}\end{array}$ & 5.16 & 8.00 & 5.83 & 5.50 & 3.83 & 4.33 & 1.88 & 3.00 \\
\hline $4 \mathrm{M}$ guanidine- $\mathrm{HCl}, \%$ & $(16.6)$ & $(23.0)$ & $(16.0)$ & $(14.1)$ & $(17.6)$ & (13.3) & (18.4) & (11.8) \\
\hline Total protein, mg & 12.96 & 16.64 & 12.00 & 13.95 & 7.08 & 10.03 & 6.38 & 8.00 \\
\hline
\end{tabular}

${ }^{1}$ Mouse brains, altogether $24 \mathrm{~g}$ in control, $12 \mathrm{~g}$ in malnourished, and $12 \mathrm{~g}$ in infected groups (6 $\mathrm{g}$ in each subgroup), from 2- to 4-month-old mice were homogenized and extracted with $10 \mathrm{ml}$ each of $0.25 \%$ detergent solution separately, and centrifuged at $105,000 \times g$ for $1 \mathrm{hr}$. The sediments were extracted again with the same detergent solution. Final volume of each subgroup was adjusted to $25 \mathrm{ml}$. The columns $(0.8 \times 4 \mathrm{~cm})$ of norepinephrine or dopamine-agarose matrix were used for affinity chromatography. Brain extract, $5 \mathrm{ml}$, was placed on the columns and the unbound proteins were washed with pH 7.3 buffer. The columns were eluted with $10 \mathrm{ml}$ of $4 \mathrm{M}$ sodium chloride and then washed with $\mathrm{pH} 7.3$ buffer. They were than eluted with $4 \mathrm{M}$ guanidine- $\mathrm{HCl}$. The eluates from $4 \mathrm{M}$ sodium chloride or $4 \mathrm{M}$ guanidine- $\mathrm{HCl}$ were dialyzed separately against distilled water and pH 7.3 buffer. The values of protein contents were the averages of triplicate samples: SE were less than $10 \%$ of the means. 
Table 2. Dopamine-binding brain protein, isolated by affinity chromatograph.1

\begin{tabular}{|c|c|c|c|c|c|c|c|c|}
\hline \multirow[b]{2}{*}{$\begin{array}{l}\text { Brăin protein, } \\
\text { solubilized with } \\
\text { detergent }\end{array}$} & \multicolumn{4}{|c|}{ Control } & \multicolumn{2}{|c|}{ Perinatal malnutrition } & \multicolumn{2}{|c|}{ Neonatal infection } \\
\hline & $\begin{array}{l}\mathrm{pH} 7.3 \\
\text { buffer }\end{array}$ & $\begin{array}{l}\text { Triton } \\
\mathrm{X}-100\end{array}$ & $\begin{array}{l}\text { Sodium } \\
\text { deoxy- } \\
\text { cholate }\end{array}$ & Lubrol PX & $\begin{array}{l}\text { pH } 7.3 \\
\text { buffer }\end{array}$ & Lubrol PX & $\begin{array}{l}\mathrm{pH} 7.3 \\
\text { buffer }\end{array}$ & Lubrol PX \\
\hline \multicolumn{9}{|l|}{ Protein content (mg) } \\
\hline Brain extract $(5 \mathrm{ml})$ & 30.7 & 34.8 & 36.5 & 39.0 & 21.8 & 32.5 & 22.5 & 25.5 \\
\hline $\begin{array}{l}\text { Pass through column and } \\
\text { washing }\end{array}$ & 20.4 & 26.1 & 27.0 & 25.2 & 12.6 & 16.5 & 6.25 & 7.50 \\
\hline \multicolumn{9}{|l|}{ Eluate } \\
\hline $4 \mathrm{M} \mathrm{NaCl}$ protein, $\mathrm{mg}$ & 3.25 & 3.08 & 4.23 & $\begin{array}{r}6.02 \\
(15.4)\end{array}$ & $\begin{array}{r}5.35 \\
(24.6)\end{array}$ & $\begin{array}{r}4.88 \\
(15.0)\end{array}$ & $\begin{array}{r}9.25 \\
(41.1)\end{array}$ & $\begin{array}{r}9.00 \\
(35.3)\end{array}$ \\
\hline $\begin{array}{l}4 \mathrm{M} \mathrm{NaCl} \text { protein, } \% \\
4 \mathrm{M} \text { guanidine- } \mathrm{HCl} \text { protein. }\end{array}$ & $(10.6)$ & (8.9) & $\begin{array}{r}(11.6) \\
3.67\end{array}$ & $\begin{array}{r}(15.4) \\
2.50\end{array}$ & 1.50 & 1.66 & 2.62 & $\begin{array}{r}(35.0) \\
3.00\end{array}$ \\
\hline $\begin{array}{l}4 \mathrm{M} \text { guanidine- } \mathrm{HCl} \text { protein, } \\
\mathrm{mg}\end{array}$ & 2.00 & 3.00 & 3.67 & & & & & \\
\hline $4 \mathrm{M}$ guanidine- $\mathrm{HCl}$ protein, & $(6.5)$ & $(8.6)$ & $(10.0)$ & $(6.4)$ & $(6.9)$ & $(5.1)$ & $(11.7)$ & (11.8) \\
\hline Total protein, $\mathrm{mg}$ & 5.25 & 6.08 & 7.90 & 8.52 & 6.85 & 6.54 & 11.87 & 12.00 \\
\hline
\end{tabular}

${ }^{1}$ The preparation of brain extracts and conditions for eluting chromatographic columns were the same as described in Table 1 . Brain extracts ( 5 ml) were placed on the chromatographic columns of dopamine-agarose matrix. The values of protein contents were the averages of triplicate samples: SE were less than $10 \%$ of the means.

Table 3. Binding activity of $\left[{ }^{3} \mathrm{H}\right]$ norepinephrine $\left(\left[{ }^{3} \mathrm{H}\right] \mathrm{NE}\right)$ to brain protein of mice exposed to perinatal malnutrition and neonatal infection $^{1}$

\begin{tabular}{|c|c|c|c|c|c|c|}
\hline \multirow[b]{2}{*}[{}^{3}\mathrm{H}]{$\mathrm{NE}$ binding activity } & \multicolumn{3}{|c|}{ Soluble fraction } & \multicolumn{3}{|c|}{ Particulate fraction } \\
\hline & Control & $\begin{array}{l}\text { Perinatal } \\
\text { malnutrition }\end{array}$ & $\begin{array}{l}\text { Neonatal } \\
\text { infection }\end{array}$ & Control & $\begin{array}{l}\text { Perinatal } \\
\text { malnutrition }\end{array}$ & $\begin{array}{l}\text { Neonatal } \\
\text { infection }\end{array}$ \\
\hline \multicolumn{7}{|c|}{$\begin{array}{l}\text { Specific binding activity, pmol }\left[{ }^{3} \mathrm{H}\right] \mathrm{NE} / \mathrm{mg} \\
\text { protein }\end{array}$} \\
\hline Brain extract & 0.557 & 0.730 & 0.319 & 1.77 & 0.842 & 0.553 \\
\hline \multicolumn{7}{|c|}{$\begin{array}{l}\text { Brain protein isolated by affinity chro- } \\
\text { matography, eluate }\end{array}$} \\
\hline $4 \mathrm{M} \mathrm{NaCl}$ & 12.3 & 23.8 & 4.17 & 31.1 & 39.7 & 5.26 \\
\hline $4 \mathrm{M}$ guanidine- $\mathrm{HCl}$ & 54.3 & 39.1 & 10.5 & 88.4 & 56.5 & 22.6 \\
\hline \multicolumn{7}{|l|}{ Total binding activity, pmol $\left[{ }^{3} \mathrm{H}\right] \mathrm{NE}$} \\
\hline Brain extract $(5 \mathrm{ml})$ & 17.1 & 15.9 & 7.18 & 69.0 & 27.4 & 14.1 \\
\hline \multicolumn{7}{|c|}{$\begin{array}{l}\text { Brain protein isolated by affinity chro- } \\
\text { matography, eluate }\end{array}$} \\
\hline $4 \mathrm{M} \mathrm{NaCl}$ & 95.9 & 77.4 & 18.8 & 262 & 226 & 26.3 \\
\hline $4 \mathrm{M}$ guanidine- $\mathrm{HCl}$ & 280 & 150 & 197 & 486 & 245 & 67.8 \\
\hline Total & 376 & 227 & 216 & 748 & 471 & 94.1 \\
\hline
\end{tabular}

${ }^{1}$ A 0.6 -mg brain protein sample in $1.5 \mathrm{ml} \mathrm{pH} 7.3$ buffer containing $0.01 \mathrm{M}$ Tris-hydrochloride, 2 mM magnesium chloride, $0.5 \mathrm{mM} \beta$-mercaptoethanol was placed in dialysis tube and dialyzed against $10 \mathrm{ml} 0.2 \mu \mathrm{Ci} \mathrm{DL}-\left[7_{-}{ }^{3} \mathrm{H}\right]$ norepinephrine in the same buffer for 24 hr at $4^{\circ}$. Particulate fractions were prepared by solubilizing the particulate sites of brain homogenate with detergent, and Lubrol PX. Soluble fractions were prepared by extracting the brain soluble protein with pH 7.3 buffer. The values were expressed as the averages of triplicate samples: SE were less than 1 of the means.

in the infected group as against $376 \mathrm{pmol}$ in the control group; in the particulate fraction, the total activity was $94.1 \mathrm{pmol}$ in the infected animals as against $748 \mathrm{pmol}$ in the controls.

The binding activity of $\left[{ }^{14} \mathrm{C}\right] \mathrm{DM}$ to brain protein in the soluble fraction was high in the brain extract of malnourished and infected groups. In the infected group, the $\left[{ }^{14} \mathrm{C}\right] \mathrm{DM}$ binding activity was decreased in the protein fraction obtained from affinity chromatography. Specific and total binding activities were also greatly reduced in the particulate fraction samples of the infected group. In the malnourished group, the specific binding activity of $\left[{ }^{14} \mathrm{C}\right] \mathrm{DM}$ was not as severely affected as that of the infected group.

PURIFICATION OF BRAIN PROTEIN BY SEPHADEX CHROMATOGRAPHY AND SPECIFIC BINDING FOR ["H]NE AND [ $\left[{ }^{14} \mathrm{C}\right] \mathrm{DM}$

Figure 1 shows the purification of catecholamine-binding brain protein by Sephadex G-25 and G-100 chromatography and the specific binding for $\left[{ }^{3} \mathrm{H}\right] \mathrm{NE}$ and $\left[{ }^{14} \mathrm{C}\right] \mathrm{DM}$. The brain protein isolated from affinity chromatography, showed a single peak on Sephadex G-25 chromatography. $\left[{ }^{3} \mathrm{H}\right] \mathrm{NE}$ was bound specifically to the brain protein and distributed in the same position as the protein peak. In further fractionation with Sephadex G-100, there were two peaks; a minor peak was located in the position of small molecular weight compound. $\left[{ }^{3} \mathrm{H}\right] \mathrm{NE}$ was also distributed in the same position as the protein peaks. Similar results were found for the distribution patterns of $\left[{ }^{14} \mathrm{C}\right] \mathrm{DM}$ binding protein in Sephadex G-25 and G-100 chromatography.

\section{SODILM DODECYI. SULIATE-POLYACRYLAMIDE GEL ELECTRO-} PIIORESIS

Figure 2 shows the electrophoretic patterns of NE-binding brain proteins obtained from the main peak of Sephadex G-100 chroma- 
Table 4. Binding activity of $\left[{ }^{14} \mathrm{C}\right]$ dopamine $\left(\left[{ }^{14} \mathrm{C}\right] D \mathrm{M}\right)$ to brain protein of mice exposed to perinatal malnutrition and neonatal infection ${ }^{1}$

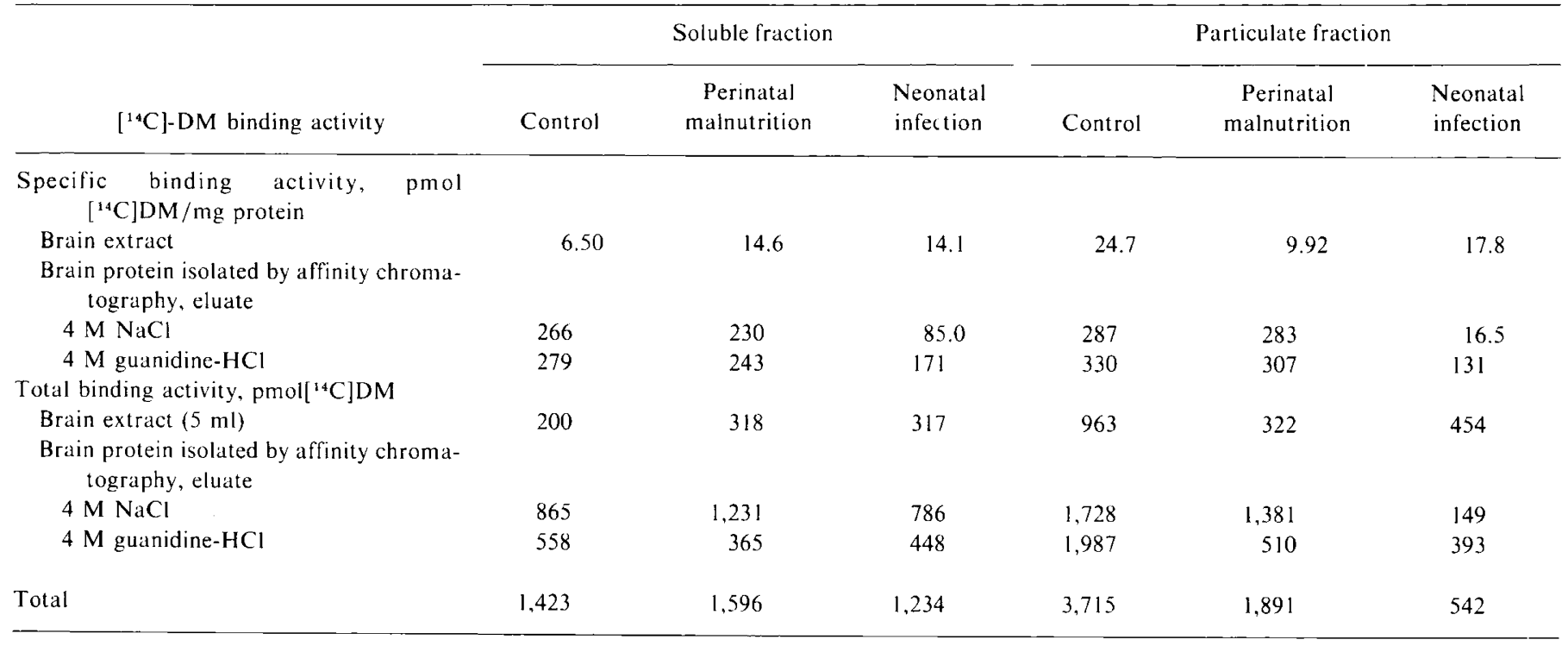

${ }^{1}$ Radioactivity of $0.1 \mu \mathrm{Ci}\left[2-{ }^{14} \mathrm{C}\right]$ dopamine in $10 \mathrm{ml} \mathrm{pH} 7.3$ Tris buffer was used. The experimental conditions for the determination of binding activity were the same as those described in Table 3. The values were expressed as the averages of triplicate samples: SE were less than $10 \%$ of the means.

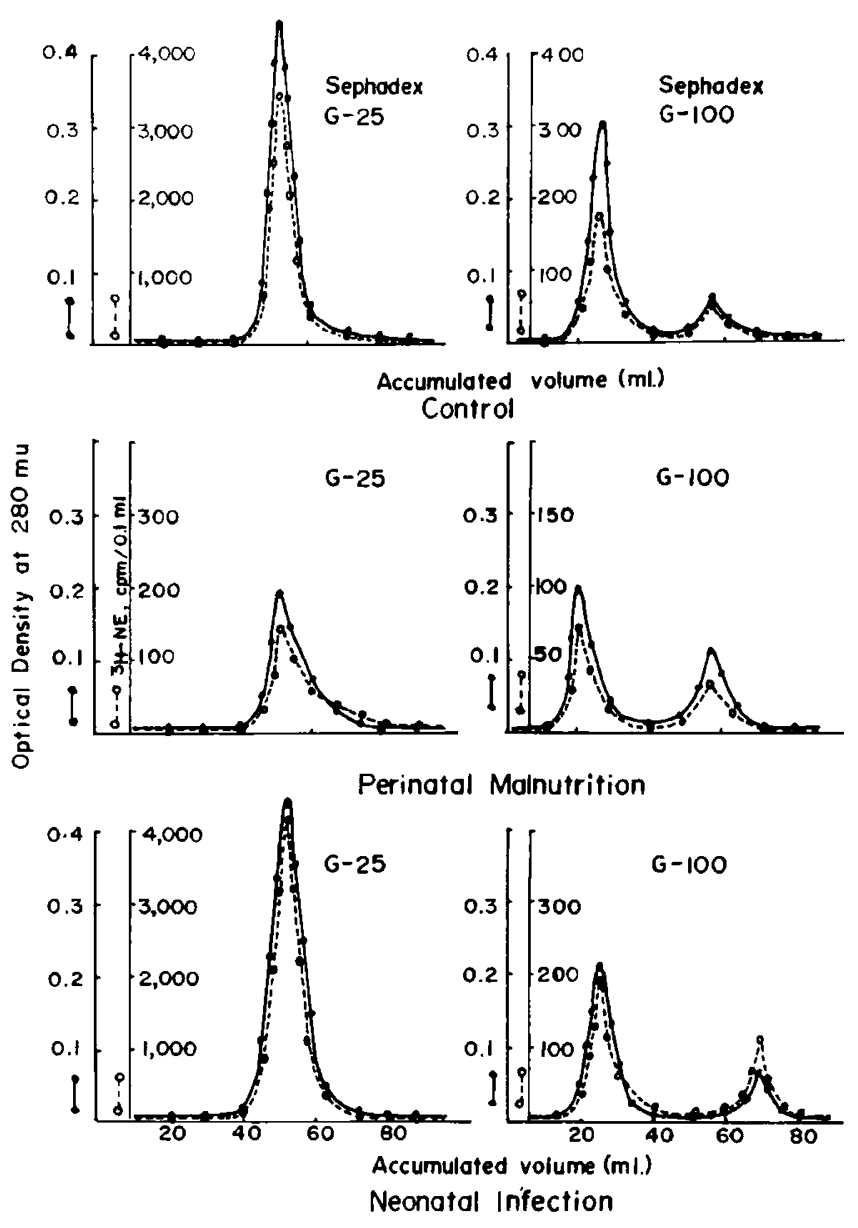

Fig. 1. Purification of norepinephrine (NE)-binding protein by Sephadex G-25 and G-100 chromatography and the specific binding for $\left[{ }^{3} \mathrm{H}\right] \mathrm{NE}$. The NE-binding brain proteins, isolated from affinity chromatography, were dissolved in pH 7.5 Tris-buffer, received $10 \mu \mathrm{Ci}\left[{ }^{3} \mathrm{H}\right] \mathrm{NE}$, and incubated at $37^{\circ}$ for $1 \mathrm{hr}$. After the incubation, the mixture was condensed and applied to a Sephadex G-25, $2 \times 40 \mathrm{~cm}$ column, equilibrated with $0.1 \mathrm{M}$ ammonium bicarbonate. The peak fractions were combined, condensed, and passed through Sephadex G-100, $1.6 \times 54 \mathrm{~cm}$. The protein samples were eluted with $0.1 \mathrm{M}$ ammonium bicarbonate at $25^{\circ}$.

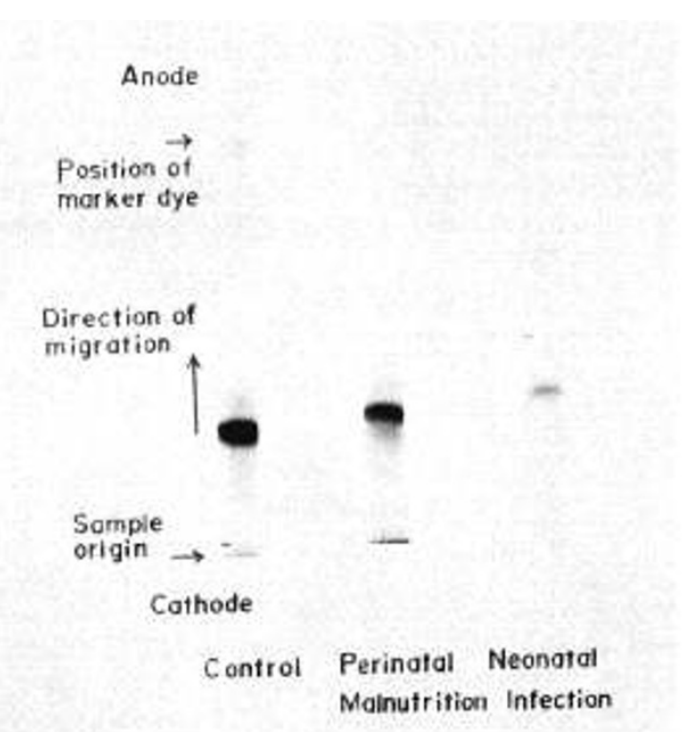

Fig. 2. Sodium dodecyl sulfate-polyacrylamide gel electrophoresis. The norepinephrine-binding brain proteins obtained from the Sephadex G-25 and G-100 chromatography were treated with $0.2 \%$ sodium dodecyl sulfate and fractionated in $10 \%$ polyacrylamide gel disc electrophoresis. Electrophoresis was carried out in $0.05 \mathrm{M}$ sodium phosphate buffer, $\mathrm{pH} 7.2$ at $25^{\circ}$ with a current of $5 \mathrm{ma} / \mathrm{gel}$ tube for $4 \mathrm{hr}$. The gels were fixed and stained in $0.25 \%$ Coomassie brilliant blue solution.

tography. In experimental and control groups, one major band was observed in the brain proteins located in the position of molecular weight approximately 70,000 . Similar results were found for the electrophoresis of DM-binding brain proteins in experimental and control groups: one major band was observed in the polyacrylamide gel.

\section{DETERMINATION OF MOLECULAR WEIGHT OF BRAIN PROTEIN}

Figure 3 shows the results of molecular weight determination by the Sephadex G-100 filtration method. The average molecular weights were 75,000 in the control group (range 65,000-85,000), 70,000 in the malnourished group (range 60,000 80,000), and 65,000 in the infected group (range $57,000-73,000$ ). 
AMINO ACID COMPOSITION OF CATECHOLAMINE-BINDING PROTEIN

Table 5 shows the amino acid composition of NE- or DM-binding protein purified by the Sephadex G-25 and G- 100 chromatography in mice exposed to perinatal malnutrition and neonatal

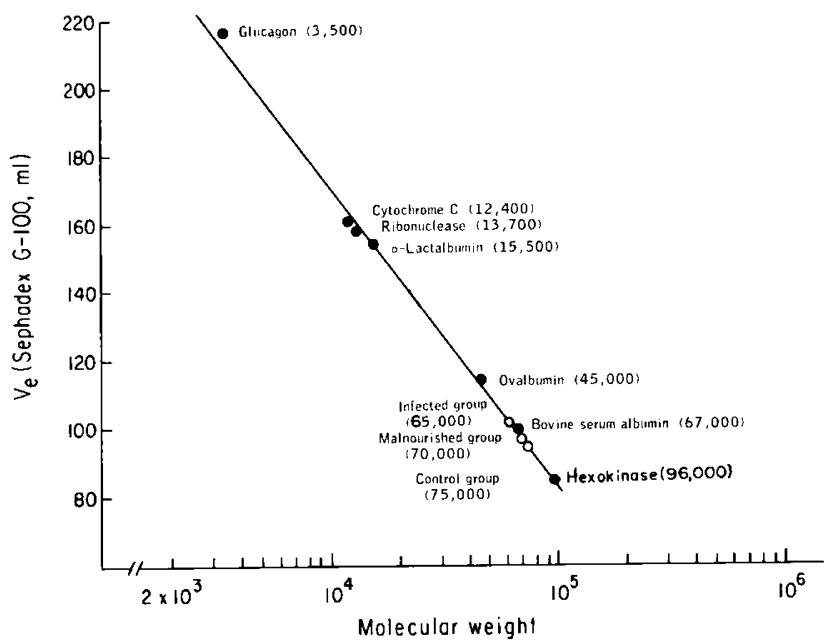

Fig. 3. Molecular weight determination of brain protein by Sephadex ge filtration method. Various authentic standards and brain protein preparations were dissolved separately in $\mathrm{pH} 7.5$ Tris-buffer, containing $0.1 \mathrm{M}$ potassium chloride, $5 \mathrm{mg}$ in $2 \mathrm{ml}$, and applied to a $\mathrm{cm}$ Sephadex G-100 column, $2 \times 58 \mathrm{~cm}$; two standard proteins were applied at one time. The flow rate was maintained at $30 \mathrm{ml} / \mathrm{hr}$ and the experimental procedure was done at room temperature $\left(25^{\circ}\right)$. The molecular weight of brain protein was determined from the plots of elution volume against the log molecular weight for standard proteins. infection. The catecholamine-binding brain protein contained high contents of acidic amino acid (glutamic acid, aspartic acid) and of the basic amino acid, lysine.

No significant differences were observed in NE-binding protein between malnourished and control groups with regard to most amino acids, although changes in lysine, serine, and alanine residues were found. The DM-binding protein in these animals showed decreased content of most amino acids and increased methionine residue.

The catecholamine-binding brain protein of infected mice was decreased in many amino acid contents compared with that of control animals. These results revealed that neonatal infection brought about profound changes in structure and formation of catecholamine-binding brain protein

\section{DISCUSSION}

Pathways of the catecholamine biosynthesis in brain involve the hydroxylation of tyrosine to dihydroxyphenylalanine (DOPA), and decarboxylation of DOPA to DM. DM moves into the catecholamine storage granules and is hydroxylated to form NE (27). The granules at nerve endings contain ATP in a molar ratio of NE to ATP of $4: 1$ and are associated with a specific protein to form NE-ATP-protein complex $(14,15)$. Such ATP-protein complex binds and stores NE. NE is released from the nerve terminals during nerve stimulation and binds to the postsynaptic receptor sites to trigger the physiologic response of the postsynaptic cells to the transmitter.

In the present study, the catecholamine-binding proteins were solubilized with detergent and isolated from the mouse brain. Such brain proteins can bind tightly and specifically to NE or DM and may be related to the specific protein in the storage granule to form NE-ATP-protein complex or they may be a part of a receptor

Table 5. Amino acid composition of catecholamine-binding brain protein from mice exposed to perinatal malnutrition and neonatal infection $^{1}$

\begin{tabular}{|c|c|c|c|c|c|c|c|c|c|c|c|c|}
\hline \multirow[b]{3}{*}{$\begin{array}{l}\text { Catecholamine- } \\
\text { binding brain } \\
\text { protein, amino } \\
\text { acids }\end{array}$} & \multicolumn{4}{|c|}{ Control } & \multicolumn{4}{|c|}{ Perinatal malnutrition } & \multicolumn{4}{|c|}{ Neonatal infection } \\
\hline & \multicolumn{2}{|c|}{ Norepinephrine } & \multicolumn{2}{|c|}{ Dopamine } & \multicolumn{2}{|c|}{ Norepinephrine } & \multicolumn{2}{|c|}{ Dopamine } & \multicolumn{2}{|c|}{ Norepinephrine } & \multicolumn{2}{|c|}{ Dopamine } \\
\hline & $\begin{array}{c}\mu \mathrm{mol} / \\
\mathrm{mg}\end{array}$ & $\begin{array}{l}\text { Resi- } \\
\text { dues/ } \\
\text { mole- } \\
\text { cule }\end{array}$ & $\begin{array}{c}\mu \mathrm{mol} / \\
\mathrm{mg}\end{array}$ & $\begin{array}{l}\text { Resi- } \\
\text { dues/ } \\
\text { mole- } \\
\text { cule }\end{array}$ & $\begin{array}{c}\mu \mathrm{mol} / \\
\mathrm{mg}\end{array}$ & $\begin{array}{l}\text { Resi- } \\
\text { dues/ } \\
\text { mole- } \\
\text { cule }\end{array}$ & $\begin{array}{c}\mu \mathrm{mol} / \\
\mathrm{mg}\end{array}$ & $\begin{array}{l}\text { Resi- } \\
\text { dues/ } \\
\text { mole- } \\
\text { cule }\end{array}$ & $\begin{array}{c}\mu \mathrm{mol} / \\
\mathrm{mg}\end{array}$ & $\begin{array}{l}\text { Resi- } \\
\text { dues/ } \\
\text { mole- } \\
\text { cule }\end{array}$ & $\begin{array}{c}\mu \mathrm{mol} / \\
\mathrm{mg}\end{array}$ & $\begin{array}{l}\text { Resi- } \\
\text { dues/ } \\
\text { mole- } \\
\text { cule }\end{array}$ \\
\hline Lysine & 0.596 & 45 & 0.630 & 47 & 0.440 & 31 & 0.241 & 17 & 0.438 & 29 & 0.363 & 24 \\
\hline Histidine & 0.137 & 10 & 0.128 & 10 & 0.082 & 6 & 0.073 & 5 & 0.084 & 6 & 0.085 & 6 \\
\hline Arginine & 0.323 & 24 & 0.270 & 20 & 0.215 & 15 & 0.106 & 7 & 0.118 & 8 & 0.199 & 13 \\
\hline Aspartic acid & 1.056 & 79 & 1.182 & 89 & 0.960 & 67 & 0.582 & 41 & 0.578 & 38 & 0.535 & 35 \\
\hline Threonine & 0.511 & 38 & 0.527 & 40 & 0.373 & 26 & 0.229 & 16 & 0.311 & 20 & 0.335 & 22 \\
\hline Serine & 0.678 & 51 & 0.708 & 53 & 0.479 & 34 & 0.295 & 21 & 0.559 & 36 & 0.768 & 50 \\
\hline Glutamic acid & 1.122 & 76 & 1.386 & 104 & 0.966 & 68 & 0.478 & 34 & 0.930 & 61 & 0.705 & 46 \\
\hline Proline & 0.335 & 25 & 0.384 & 29 & 0.335 & 24 & 0.143 & 10 & 0.205 & 13 & 0.226 & 15 \\
\hline Glycine & 0.762 & 57 & 0.864 & 65 & 0.864 & 61 & 0.350 & 25 & 0.714 & 46 & 0.373 & 24 \\
\hline Alanine & 0.762 & 57 & 0.828 & 62 & 0.556 & 39 & 0.300 & 21 & 0.529 & 34 & 0.455 & 30 \\
\hline Half-cystine & 2 & 2 & 2 & 2 & 2 & 2 & 2 & 2 & 2 & 2 & 0.029 & 2 \\
\hline Valine & 0.292 & 22 & 0.493 & 37 & 0.239 & 17 & 0.194 & 14 & 0.517 & 34 & 0.300 & 20 \\
\hline Methionine & 0.103 & 8 & 0.141 & 11 & 0.097 & 7 & 0.451 & 32 & 0.333 & 22 & 0.108 & 7 \\
\hline Isoleucine & 0.110 & 8 & 0.162 & 12 & 0.104 & 7 & 0.140 & 10 & 0.417 & 27 & 0.233 & 15 \\
\hline Leucine & 0.465 & 35 & 0.481 & 36 & 0.284 & 20 & 0.199 & 14 & 0.702 & 46 & 0.460 & 30 \\
\hline Tyrosine & 0.301 & 23 & 0.248 & 19 & 0.183 & 13 & 0.133 & 9 & 0.205 & 13 & 0.118 & 8 \\
\hline Phenylalanine & 0.390 & 29 & 0.372 & 28 & 0.266 & 19 & 0.186 & 13 & 0.308 & 20 & 0.183 & 12 \\
\hline
\end{tabular}

${ }^{1}$ Samples were obtained from the purified brain proteins after passing through Sephadex G-25 and G-100 chromatography. Brain proteins, $1-2$ mg, were hydrolyzed in vacuo with $6 \mathrm{~N}$ hydrochloric acid at $110^{\circ}$ for $20 \mathrm{hr}$. The hydrochloric acid was removed at $25^{\circ}$ by a Büchi Rotavapor-R. The values for serine and threonine were not corrected for effect of hydrochloric acid during hydrolysis. Tryptophan was seriously destroyed by acid hydrolysis. The values of amino acids composition were the averages of triplicate samples: SE were less than $10 \%$ of the means.

${ }^{2}$ None was contained in the sample. 
molecule in postsynaptic cells. The specilicity of catecholaminebinding to microsomal particles was reported to correspond to that of the physiologic cardiac $\beta$-adrenergic receptor, and to be markedly different from that of nerve storage vesicles $(23,25)$. The present experiments did not indicate whether the catecholaminebinding brain protein was similar to the adrenergic receptor molecule but different from the specific protein in the catecholamine storage granules.

The results discussed here indicate that NE- or DM-binding brain protein can be solubilized with detergent and isolated by affinity chromatography. Perinatal malnutrition and neonatal infection had different effects on the formation and specific binding activity for catecholamines. In the malnourished group, the total NE-binding protein isolated by affinity chromatography was less than in the control group but the DM-binding protein obtained from the column was not affected. In the infected group, the quantity of NE-binding protein was also decreased, but the DM-binding protein was higher than in the control group.

The specific binding activity of $\left[{ }^{3} \mathrm{H}\right] \mathrm{NE}$ and $\left[{ }^{14} \mathrm{C}\right] \mathrm{DM}$ to brain protein was higher in the particulate fraction than in the soluble fraction. This may indicate that these catecholamine-binding molecules are associated with the membrane structure. The binding activity of $\left[{ }^{3} \mathrm{H}\right] \mathrm{NE}$ in malnourished mice was decreased in the protein fraction obtained from guanidine- $\mathrm{HCl}$ elute. In infected animals, the specific or total binding activity of $\left[{ }^{3} \mathrm{H}\right] \mathrm{NE}$ was greatly reduced

The binding activity of $\left[{ }^{14} \mathrm{C}\right] \mathrm{DM}$ to brain protein was decreased markedly in the infected group, but its specific binding activity in the malnourished group was not as severely affected as in the infected group.

From the dose-response studies of lipolysis, the apparent affinity constant for norepinephrine in fat cells of the rat was calculated as about $2 \times 10^{-7} \mathrm{M}$ to $6.5 \times 10^{-8} \mathrm{M}(9)$. The catecholamine-binding protein in mouse brain contained two binding sites with apparent dissociation constants of $2.34 \times 10^{-8} \mathrm{M}$ and $4.74 \times 10^{-7} \mathrm{M}(19)$. These values are close to those in the fat cells of the rat. Purified $\beta$-adrenergic binding protein from cardiac muscle has been reported to exist in two forms, with molecular weights of 40,000 and $160,000(24)$. The molecular weight of acetylcholine receptor in guinea pig brain is 86,000 with two binding sites (4). The molecular weight of the catecholamine-binding brain protein studied here is about 75,000; close to that of acetylcholine receptor. The molecular size of the catecholamine-binding protein in the infected group was slightly reduced $(65,000)$. It is not known whether the low molecular weight of brain protein is caused by dissociation of protein into subunits or to qualitative change in the structure.

Some highly acidic proteins, such as S-100 and 14-3-2, have been found specifically in the central nervous system. The $S-100$ protein has a molecular weight of 21,000 , containing three subunits of molecular weight 7,000 (10), and a high content of glutamic acid and aspartic acid $(28,29,36)$. The catecholamine-binding brain protein is similar in amino acid composition to $S-100$ brain protein in that it contains a high content of glutamic acid and aspartic acid. Catecholamine transmitter, when released from the nerve terminal during the period of stimulation, combines with the adrenergic receptor and increases the ionic permeability to the membrane $(12,13)$. It is not clear at present time whether the catecholamine-binding brain protein is involved in the ion transport and increase the ionic permeability of the membrane.

Remarkable differences were observed between the infected and control groups with regard to catecholamine-binding brain protein. The amino acid contents of the brain protein from the infected group were greatly decreased and the protein structure disorganized. These results suggest that some profound changes in the structure and formation of the catecholamine-binding brain protein have been induced by neonatal infection. Some mechanisms for altered biosynthesis of brain protein by perinatal malnutrition have been postulated. These include the decrease of active DNA polymerase for DNA synthesis, excessive ribonuclease activity
(39), or the disaggregation of polysomes (31). On the other hand, the hormone treatment was found to correct impaired amino acid incorporation into the brain protein of infected animals (17). In the present study, it is still unknown whether the altered amino acid compositions of the catecholamine-binding brain protein are caused by the mechanism of transcription or by translation error. The alteration may be caused by the impaired regulatory mechanisms involving the hormonal functions and related metabolisms.

\section{SUMMARY}

Perinatal malnutrition and neonatal infection have caused changes in the formation and specific binding activity of catecholamine-binding brain protein. The total amount of NE-binding brain protein was decreased in the malnourished and infected groups. The specific and total binding activity of $\left[{ }^{3} \mathrm{H}\right] \mathrm{NE}$ to brain protein was greatly reduced in the infected group and decreased in an elute fraction of the malnourished group. The binding activity of $\left[{ }^{14} \mathrm{C}\right] \mathrm{DM}$ was decreased markedly in the infected group, but its specific activity was not affected severely in the malnourished group. The molecular weight of the catecholamine-binding protein in the infected group was slightly reduced. The DM-binding protein of the malnourished group had markedly low amino acid content. The infected group exhibited remarkable changes in NEand DM-binding brain protein. These results reveal that neonatal infection and perinatal malnutrition bring about some fundamental changes in the structure of catecholamine-binding brain protein.

\section{REFERENCES AND NOTES}

1. Adlard, B. P. F., and Dobbin, J.: Vulnerability of developing brain. V. Effects of fetal and postnatal undernutrition on regional brain enzyme activities in three-week-old rats. Pediat. Res., 6: 38 (1972).

2. Andrews, P.: Estimation of the molecular weights of proteins by Sephadex gel-filtration. Biochem. J., 9l: 222 (1964)

3. Bilezikian, J. P., and Aurbach, G. D.: A beta-adrenergic receptor of the turkey erythrocyte. I. Binding of catecholamine and relationship to adenylate cyclase activity. J. Biol. Chem., 248: 5577 (1973)

4. Bosmann, H. B.: Acetylcholine receptor. 1. Identification and biochemical characteristics of a cholinergic receptor of guinea pig cerebral cortex. J. Biol. Chem., 247: 130 (1972).

5. Chasin, M., Rivkin, I., Mamrak, F., Samaniego, S. G., and Hess, S. M.: $\alpha$ - and $\beta$-Adrenergic receptors as mediators of accumulation of cyclic adenosine $3^{\prime}, 5^{\prime}$-monophosphate in specific areas of guinea pig brain. J. Biol. Chem., 246: 3037 (1971).

6. Cuatrecasas, P.: Affinity chromatography of macromolecules. Advan. Enzymol., 36: 29 (1972)

7. Cuatrecasas, P.: Problems in receptor identification: catecholamines. N. Engl. J. Med.. 291: 206 (1974)

8. Cuatrecasas, P., and Anfinsen, C. B.: Affinity chromatography. Methods Enzymol., 22: 345 (1971).

9. Cuatrecasas, P., Tell, G. P. E., Sica, V., Parikh, I., and Chang, K. J Noradrenaline binding and the search for catecholamine receptors. Nature, 247: 92 (1974)

10. Dannies. P. S., and Levine, L.: Demonstration of subunits in beef brain acidic protein (S-100). Biochem. Biophys. Res. Commun. 37: 587 (1969).

11. Davis, B. J.: Disc electrophoresis. II. Method and application to human serum proteins. Ann. N. Y. Acad. Sci., 121: 404 (1964).

12. Gardner. J. D., Klaeveman, H. L., Bilezikian, J. P., and Aurbach, G. D.: Effect of beta-adrenergic catecholamines on sodium transport in turkey erythrocytes. J. Biol. Chem., 248: 5590 (1973)

13. Haylett. D. G.. and Jenkinson, D. H.: The receptors concerned in the actions of catecholamines on glucose release, membrane potential and ion movements in guinea-pig liver. J. Physiol., 225: 721 (1972).

14. Kirshner, N.: Uptake of catecholamines by a particulate fraction of the adrenal medulla. J. Biol. Chem., 237: 2311 (1962).

15. Kirshner, N., Sage, H. J.. Smith, W. J., and Kirshner, A. G.: Release of catecholamines and specific protein from adrenal glands. Science, 154: 529 (1966).

16. Kohrman, A. F.: Patterns of development of adenyl cyclase activity and norepinephrine responsiveness in the rat. Pediat. Res., 7: 575 (1973).

17. Lee, C. J.: Biosynthesis and characteristics of brain protein and ribonucleic acid in mice subjected to neonatal infection or undernutrition. J. Biol. Chem., 245 $1998(1970)$.

18. Lee, C. J.: Neonatal infection, maternal malnutrition, and fetal brain metabolism. Nutr. Rep. Int., 7: 333 (1973).

19. Lee, C. J.: Catecholamine-binding protein in mouse brain: Isolation and characterization. Brain Res., 81: 497 (1974).

20. Lee, C. J., and Dubos, R.: Lasting biological effects of early environmental 
influences. IV. Notes on the physicochemical and immunological characterisics of an ent Med.. 130: 955 (1969).

21. Lee, C. J., and Dubos, R : Lasting biological effects of early environmental influences. VII Metabolism of adenosine $3^{\prime}, 5^{\prime}$-monophosphate in mice influences. VIl. Metabolism of adenosites. Jex. Med. 135: 220 (1972).

22. Lee $C$ environmental influences. VIII. Effects of neonatal infection, perinatal malnutrition and crowding on catecholamine metabolism of brain. J. Exp. Med., 136: 1031 (1972).

23. Lefkowitz, R J.. and Haber, E.: A fraction of the ventricular myocardium that has the specificity of the cardiac beta-adrenergic receptor. Proc. Nat. Acad. Sci. U.S.A., 68: 1773 (1971).

24. Lefkowitz, R. J., Haber, E., and O'Hara, D.: Identification of the cardiac Lefkowitz, R. J., Haber, E., and Solubilization and purification by affinity beta-adrenergic receptor protein: Solubilization and purification b

chromatography. Proc. Nat. Acad. Sci. U.S.A., 69: 2828 (1972).

25. Lefkowitz, R. J., Sharp. G. W. G., and Haber, E.: Specific binding of $\beta$-adrenergic catecholamines to Biol. Chem., 248: 342 (1973)

26. Miledi. R., Molinoff, P., and Potter, L. T. Isolation of the cholinergic receptor protein of Torpedo electric tissue. Nature, 449: 554 (1971)

27. Molinff, P. B. and Axelrod, J-Biochemistry of catecholamine. Ann. Rev. Biochem., 40: 465 (1971).

28. Moore B. W. A soluble protein characteristics of the nervous system. Biochem. Biophys. Res. Commun., 19: 739 (1965).

29. Moore, B. W., and Perez, V. J.: In: F. C. Carlson: Physiological and Biochemical Aspects of Nervous Integrity. p. 343 (Prentice-Hall, Englewood Cliffs, N.J. 1968).

30. Moore. S., and Stein, W. H.: Chromatographic determination of amino acids by the use of automatic recording equipment. Methods Enzymol. 6: 819 (1963)

31. Munro, H. N.: Metabolic regulation in relation to cell development. Fed. Proc. 29: 1490 (1970).

32. Naeye, R L Blanc, W., and Paul, C.: Effect of maternal nutrition on the human fetus. Pediatrics, 52: 494 (1973)

33. Schramm, M. Feinstein, H., Naim, E., Lang, M., and Lasser, M.: Epinephrine

Copyright (C) 1975 International Pediatric Research Foundation, Inc. binding to the catecholamine receptor and activation of the adenylate cyclase in (1972).

4. Spackman, D. H. Stein, W. H.. and Moore, S.: Automatic recording apparatus for use in the chromatography of amino acids. Anal. Chem., 30: 1190 (1958).

5. Tell, G. P. E., and Cuatrecasas, P.: $\beta$-Adrenergic receptors: Stereospecificity and lack of affinity for catechols. Biochem. Biophys. Res. Commun., 57: 793 (1974).

36. Vincendon, G. Waksman, A. Uyemura, K., Tardy, J., and Gombos, G. Ultracentriog Brochem. Ultracentrifugal behavior
Biophys., 120:233 (1967).

77. Weber, K., and Osborn. M.: The reliability of molecular weight determination by dodecyl sulfate-polyacrylamide gel electrophoresis. J. Biol. Chem., 244: 4406 (1969).

3. Winick, M. The malnutrition on cellular growth of human brain. Pediat. Res., 3: 181 (1969).

and cellular growth in the brain. Existence of critical periods. In: Lipids. Malnutrition and the Developing Brain. 199 (Ciba Foundation Symposium, 1971).

ing Brain, p. Has

40. Charles River Breeding Laboratories, Inc.

41. Dietrich \& Gambrill, Inc., Frederick, Md.

43. Eastman Kodak Co Rochester, N. Y.

44. Schwarz BioResearch. Inc., Orangeburg, N. Y

45. Calbiochem, Los Angeles, Calif.

46. ICl America, Inc., Bridgeport, Conn

47. Union Carbide Corp., Chicago, III.

48. Fisher Scientific Co., Fair Lawn, N. J.

48. Fister Scientic Co. Fair Lawn Lee, N J

50. Buchler Instrument. Chemical Co., St. Louis, Mo.

51. Worthington Biochemical Corp., Freehold, N. J.

52. Brinkmann Instruments, Westbury, N. Y

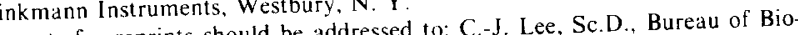

53. Requests for reprints should be addressed to: C.-Jethesda, Md. 20014 (USA) logics, Bldg. 29, National Institutes of
Accepted for publication April 10, 1975.

\title{
Inhibition of RNA Synthesis by Acetyl Salicylate and Actinomycin D during Early Development in the Mouse
}

\author{
ANIL BUKHERJEE, MARIA CHAN, RICHARD WAITE, MARTIN I. METZGER, AND SUMNER J. \\ YAFFEE ${ }^{129}$ \\ Department of Pediatrics, School of Medicine, State University of New York at Buffalo, and Children's Hospital, \\ Buffalo, New York, USA
}

\section{Extract}

Experiments were designed to ascertain and compare the effects of acetyl salicylate and actinomycin D on RNA synthesis in mouse oocytes in vitro and in vivo. After exposure to the drugs the effects on RNA synthesis were measured by incorporation of $\left[{ }^{3} \mathrm{H}\right]$ uridine and autoradiography. The results indicate that acetyl salicylate inhibits RNA synthesis in the treated oocytes as does actinomycin $D$. The only difference in the effects of these two drugs is that salicylate inhibits RNA synthesis to a much lesser degree than does actinomycin D. Effects from a short exposure to salicylate may be reversible; the same effects with actinomycin $D$ cannot be reversed. In utero exposure of the female fetus may lead to partial or total sterility (depending on the dose and time of exposure) of that fetus and/or abnormal development of the progeny from those mice (F2).
These results suggest that RNA synthesis in early oogenesis is a vital part of later development of the oocytes in adult mouse ovary. Inhibition of RNA may be one of the causes of malformations and sterility.

\section{Speculation}

During early stages of development a species of RNA (known as masked messenger RNA) is synthesized by the oocyte nucleus and masked mestilization this RA is utilized for stored in the cytoplasm. After fertilization this RNA is utilized for the production of proteins necessary for the development of the embryo. If this RNA synthesis is inhibited by some agent e.g., drugs) malformation or infertility could ensue in the female progeny. 